Life Sciences Contribution $\mathbf{8 6}$
Royal Ontario Museum

A Review of the

Water Mite Genus

Nautarachna (Acari:

Parasitengona:Pionidae)

$\operatorname{Ian}$ M. Smith

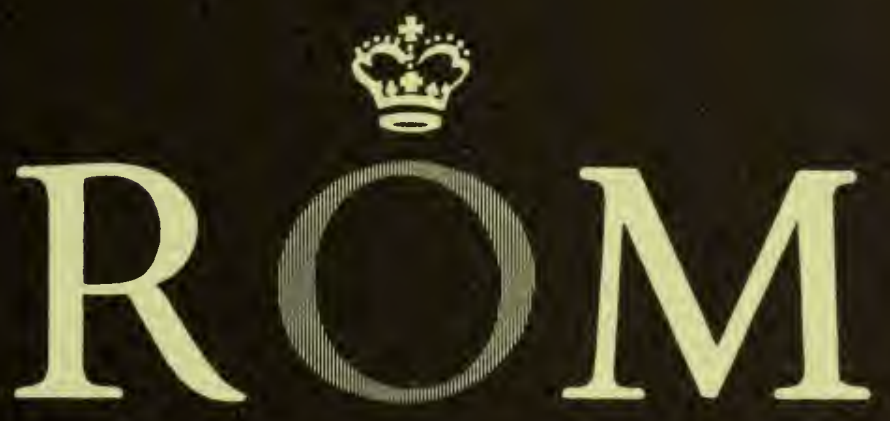


Digitized by the Internet Archive in 2011 with funding from University of Toronto 
LIFE SCIENCES CONTRIBUTIONS

ROYAL ONTARIO MUSEUM

NUMBER 86

IAN M. SMIth A Review of the Water Mite Genus

Nautarachna

(Acari: Parasitengona:

Pionidae)

Publication date: 18 December 1972

Suggested citation: Life Sci. Contr., R. Ont. Mus. 


\section{ROYAL ONTARIO MUSEUM \\ PUBLICATIONS IN LIFE SCIENCES}

The Royal Ontario Museum publishes three series in the Life Sciences:

LIFE SCIENCES CONTRIBUTIONS, a numbered series of original scientific publications, including monographic works.

LIFE SCIENCES OCCASIONAL PAPERS, a numbered series of original scientific publications, primarily short and usually of taxonomic significance.

LIFE SCIENCES MISCELlanEOUS PUBLICATIONS, an unnumbered series of publications of varied subject matter and format.

All manuscripts considered for publication are subject to the scrutiny and editorial policies of the Life Sciences Editorial Board, and to review by persons outside the Museum staff who are authorities in the particular field involved.

LIFE SCIENCES EDITORIAL BOARD, 1972-1973

$\begin{array}{ll}\text { Editors: } & \text { J.R.TAMSITT } \\ & \text { D.BARR } \\ & \text { E. J.CROSS MAN }\end{array}$

IAN M. SMITH is a doctoral candidate in the Department of Zoology, University of Toronto. This publication is the result of research carried out in the Department of Entomology and Invertebrate Zoology, Royal Ontario Museum.

PRICE : $\$ 1.50$

(C)The Royal Ontario Museum, 1972

100 Queen's Park, Toronto, Canada

PRINTED AT THE UNIVERSITY OF TORONTO PRESS 


\title{
A Review of the Water Mite Genus Nautarachna (Acari: Parasitengona: Pionidae)
}

\begin{abstract}
Males of the genus Nautarachna are recognized for the first time by association with females of two new species described from streams in Ontario; N. muskoka from near Baysville and $N$. queticoensis from near Quetico Provincial Park. The genus Nautarachna, heretofore the only genus in the family Nautarachnidae, is placed in the family Pionidae, subfamily Pioninae, on the basis of characteristic modifications of III-L-6 and IV-L-4 in males. A new diagnosis and description are proposed for the genus Nautarachna and new synonymy is established. Two polythetic species groups, the muskoka group and the queticoensis group, are distinguished and the status of new specimens from western North America is discussed.
\end{abstract}

\section{Introduction}

The systematic status of the genus Nautarachna Moniez, 1888 has heretofore been uncertain. Most recently the genus has been considered the only representative of the family Nautarachnidae (Viets, 1936, 1956; Cook, 1960). Descriptions of the five species previously included in Nautarachna are inadequate, based on only a few female and nymphal specimens. Males have until now not been recognized, resulting in uncertainty stated by Cook (1960, p. 227): "The Nautarachnidae have been tentatively placed next to the Pionidae but the closeness of this relationship can only be determined when the type of male sexual dimorphism, if any, is known."

The type of sexual dimorphism present in Nautarachna species is now known through the association of males and females of two previously undescribed species from Ontario. This sexual dimorphism is characteristic for the pionid subfamily Pioninae. Moreover, allocation of Nautarachna species to the Pioninae is supported by the morphological similarity of males and females to those of the genus Piona. 


\section{Materials and Methods}

In the following descriptions measurements are expressed in microns in the form: mean of six individuals (minimum value-maximum value). For the male of Nautarachna muskoka n. sp., only two individuals were measured. Lengths are measured parallel to, and widths perpendicular to, the long axis of the body or appendage except in the case of the width of coxae I + II which is measured perpendicular to the suture between the coxae. The following conventions have also been adopted:

i) width of coxae I + II was measured at the level of coxoglandularium I.

ii) length of acetabular plate was measured at the level of coxoglandularium II.

iii) width of coxa IV was measured from the medial edge of the coxa to the outer edge of the insertion of leg IV.

iv) width of dorsal shield was measured at the level of lateroglandularium II.

The abbreviations used for the segments of the appendages are given by Newell (1959). 


\title{
Systematics
}

\author{
Family Pionidae Thor 1900
}

Nautarachnidae Viets, 1935, p. 664. NEW SYNONYMY.

Subfamily Pioninae Wolcott 1905

Nautarachninae Walter, 1925, p. 45. NEW SYNONYMY.

Pionellinae Viets, 1937, p. 295. NEW SYNONYMY.

\section{Genus Nautarachna Moniez 1888}

Pionella Viets, 1937, pp. 294-298. NEW SYNONYMY.

See notes under $N$. karamani.

Piona Walter, In Bader, 1955, pp. 65-67. NEW SYNONYMY.

See notes under $N$. scutata.

\section{GENERIC DIAGNOSIS}

Integument with extensive dorsal and ventral sclerotized shields in male, membranous or with extensive dorsal and ventral sclerotized shields in female; P-IV with one large, ventromedial, distally-directed, curved, setiferous tubercle in male; anterior end of coxa I bearing 2-4 heavy setae in male, 3-4 heavy setae in female; posteromedial edge of coxa IV broadly rounded in female; swimming hairs relatively few when compared with Piona spp.

\section{GENERIC DESCRIPTION}

Male: Body round, slightly flattened dorsoventrally.

Dorsum (Figs. 1b, 3b): Nearly covered by a single, large, sclerotized dorsal shield, oval and centrally located, that bears all pairs of dorsoglandularia and some pairs of lateroglandularia; separated laterally and posteriorly from ventral shield by narrow strip of unsclerotized integument, anteriorly either separated from or continuous with ventral shield between eyes.

Venter (Figs. 1a, 3a): All structures incorporated into a single, large, sclerotized ventral shield, rounded and extending dorsally up anterior, lateral and posterior surfaces of body. Coxae arranged in four groups as in Piona but with edges more or less obliterated by fusion with ventral shield. Coxae I with medial edges widely separated anteriorly, converging to near midlength, posterior halves fused with ventral shield, sutures obliterated medially, poorly defined posteromedially; each coxa I bearing 2-4 heavy setae anteriorly and three fine setae, two near medial edge in anterior half, the third posteromedially. Suture between coxa I and coxa II distinct. Coxa II marginally augmented posteriorly by extensive sclerotization of adjacent integument, including coxoglandularium I, fused with anterior edge of coxa III, suture distinct to a point immediately lateral to posteromedial edge of coxa 1; bearing three setae in anterolateral half. Coxac III fused medially, suture partial and poorly defined; each coxa III bearing four fine setae, three in anterolateral half, one medially. Suture between coxa III and coxa IV distinct except medially. Coxae IV fused medially, suture poorly defined; each coxa IV with posterior edge transversely concave, broadly angulate postero- 
laterally, weakly convex to straight laterally; posterior and lateral edges fused with ventral shield, sutures poorly defined or obliterated; bearing 3-5 fine setae near edge of insertion of leg IV, one fine seta posteromedially. Gonopore embedded in ventral shield, flanked on either side anteriorly by a group of four or five small setae, posteriorly by a group of 3-5 small setae. Acetabular plates elongate, wing-like, embedded in ventral shield; each plate extending laterally from near edge of gonopore to point just beyond level of insertion of leg IV; each bearing numerous acetabula. Coxoglandularium II embedded in ventral shield between acetabular plate and midpoint of posterior edge of coxa IV. Excretory pore and all ventroglandularia embedded in ventral shield, anteriormost pair of ventroglandularia borne on small, conical projections ventromedial to eyes.

Appendages: Capitulum partially protrusible on membranous tube of integument; P-IV (Figs. 1c, 3c) markedly modified, bearing one large, distally-directed, curved, tubercle arising near midpoint of ventromedial surface, extending nearly to end of segment, bearing two fine setae. Legs with relatively few swimming hairs; sexually dimorphic as in Piona; III-L-6 (Figs. 3d, 5a, 5d) blunt, club-shaped, bearing terminally one stout, straight spur and one large, curved claw; IV-L-4 (Figs. 5b, 5c) with deep rounded, posterodorsal concavity bearing numerous peg-like setae.

Female: Body ovoid to round, either strongly arched or slightly flattened dorsoventrally.

Dorsum (Figs. 2b, 4b): Membranous, as in Piona, bearing one pair small dorsalia, or with single, large, central, oval, sclerotized, dorsal shield separated from ventral shield anteriorly, laterally and posteriorly by narrow strip of unsclerotized integument.

Venter (Figs. 2a, 4a): Membranous, as in Piona, or with a single, large, sclerotized, ventral shield, rounded and extending dorsally up anterior and lateral surfaces of body. Coxae arranged in four groups as in Piona but with edges marginally augmented by sclerotization of adjacent integument and more or less obliterated by fusion with ventral shield when present. Coxae I with medial edges widely separated anteriorly, converging to near midlength, continuing parallel to one another for posterior half, either separated by a strip of integument or fused with ventral shield; each coxa I bearing three or four heavy setae at anterior end and three fine setae, two near medial edge in anterior half, the third posteromedially. Coxa II marginally augmented medially and posteriorly by sclerotization of adjacent integument; bearing three or four setae in anterolateral half; separated from coxa III by a narrow strip of integument bearing coxoglandularium I, or fused with anterior edge of coxa III and including coxoglandularium I. Coxa III marginally augmented medially, anteriorly and laterally by sclerotization of adjacent integument that continues as marginal extension of coxa IV medially, posteriorly and laterally; fused medially with ventral shield when present; bearing one heavy and two or three fine setae in anterolateral half and one fine seta medially. Coxa IV broadly rounded posteromedially, obtusely angled posteriorly, convex laterally; bearing three or four fine 
setae near edges of insertion of leg IV and one or two fine setae posteromedially. Gonopore borne in integument between coxae III and IV with distinct pregenital and postgenital sclerites, or embedded in ventral shield with sclerites obliterated; flanked bilaterally by two or three setae. Acetabular plates wing-like, borne in integument or embedded in ventral shield; each plate extending laterally from near edge of gonopore to a point posterior to or beyond level of insertion of leg IV; bearing numerous acetabula; with 2-4 small setae on or immediately medial to plate. Coxoglandularium II borne on small, weakly sclerotized plate in integument, or embedded in ventral shield, between acetabular plate and midpoint of posterior edge of coxa IV. Excretory pore and ventroglandularia borne on small, weaklysclerotized plates in integument or embedded in ventral shield.

Appendages: Capitulum partially protrusible on membranous tube of integument. P-IV (Figs. 2c, 4c) without setiferous tubercle. Legs (Figs. 2d, 4d) as in Piona but with fewer swimming hairs.

\section{SPECIES OF THE GENUS NAUTARACHNA}

\section{Nautarachna asperrima Moniez}

Nautarachna asperrimum Moniez, 1888, pp. 64-68.

Nautarachna asperrima Moniez. Walter, 1925, pp. 46-49, pl. 2, figs. 30-33.

This species, the generotype, was described from a nymphal specimen taken in the littoral zone of the Atlantic Ocean at Cayeux-sur-Mer, France. Walter (1925) redescribed $N$. asperrima from the type specimen and was the first to recognize its affinity with the present family Pionidae, establishing the subfamily Nautarachninae for this and the following species. No definite adult association has been established for $N$. asperrima.

\section{Nautarachna crassa (Koenike)}

Delmea crassa Koenike, 1908, pp. 704-707.

Nautarachna crassa (Koenike). Walter, 1925, p. 11.

$N$. crassa was originally described from a single female specimen taken from the Delme River at Delmenhorst, Oldenburg, Germany, and assigned to the new subfamily Delminae (Koenike, 1910). Walter (1925) synonymized Delmea with Nautarachna on the basis of similarities between the nymph of $N$. asperrima and the female of $N$. crassa. The description of the nymph of $N$. crassa by Viets (1936) confirmed the synonymy. Nautarachna females have been reported subsequently from several localities in Europe, and all have been referred to $N$. crassa despite considerable variation among the individuals taken (see Koenike, 1908 and Viets, 1936). Males of $N$. crassa have not yet been recognized with certainty (but see notes for $N$. karamani). Habeeb (1956a, 1956b, 1957) has referred a nymphal specimen from New Brunswick, Canada, to $N$. crassa. 


\section{Nautarachna karamani (Viets)}

Pionella karamani Viets, 1937, pp. 294-298. NEW SYNONYMY.

Described from a specimen collected in the Krka River at Ljubljana, Jugoslavia, this species is based on a Nautarachna male, probably that of $N$. crassa. Viets (1937) reported an imagochrysalis of $N$. crassa in the collection containing the type of $P$. karamani. Halbert (1944) subsequently reported a male, referred to $P$. karamani, and a female of Nautarachna crassa, in River Flesk, Killarney, North Kerry, Eire.

\section{Nautarachna scutata (Walter)}

Piona scutata Walter, In Bader, 1955, pp. 65-67. NEW SYNONYMY.

From the description and figures it seems that this species is also based upon a Nautarachna male. Possibly the type specimen formed the basis for the nomen nudum Nautarachna processifera in Walter's 1925 paper for the same locality, Vierwaldstattersee, Switzerland, is involved in both cases. Walter may have had evidence for the association of males and females of the genus Nautarachna at that time but if so did not publish it. It is possible that $N$. scutata is a synonym of $N$. crassa. A comprehensive comparative study of all European material is necessary to determine that systematic status of both $N$. scutata and $N$. karamani.

\section{Nautarachna neogaea (Habeeb)}

Pionella neogaea Habeeb, 1955, pp. 1-3. NEW SYNONYMY.

This species is known only from the type locality, Fallsbrook, Grand Falls, New Brunswick.

\section{Nautarachna karl-vietsi Habeeb}

Nautarachna karl-vietsi Habeeb, 1957, pp. 51-52.

This species was described from a single nymph taken in a stream near a saline spring in New Brunswick, Canada.

\section{Nautarachna pioniformis Cook}

Nautarachna pioniformis Cook, 1960, pp. 228-230.

This distinctive species was described from a female specimen taken in a stream in Wyoming, U.S.A.

\section{Nautarachna californica Cook}

Nautarachna californica Cook, 1960, pp. 227-228.

Described from a female specimen from a stream in California, this species was subsequently reported from Colorado (Young, 1969, p. 388). 


\section{Nautarachna muskoka n. sp.}

MALE: Dorsum (Fig. 1b): Dorsal shield bearing all pairs of dorsoglandularia and all but the fourth pair of lateroglandularia; continuous with ventral shield anteriorly between eyes.

Venter (Fig. 1a): Coxa I bearing three or four heavy setae at anterior end. Coxa II with one heavy seta and two fine setae in anterolateral half. Coxa Iv bearing three fine setae posterior to and one fine seta medial to edge of insertion of leg IV. Gonopore flanked anteriorly by a group of five small setae on each side. Each acetabular plate with one fine seta posteriorly and 35-45 acetabula.

Measurements (in microns): Length of coxa I, 237 (236-238); length of coxae, 425 (420-429); width of coxae I + II, 115 (112-117); width of coxa IV, 210 (206-213); width of acetabular plate, 247 (243-250); length of acetabular plate, 49 (47-50); length of gonopore, 48 (45-50); length of chelicera, 251 (248-253); length of dorsal shield, 547 (545-549); width of dorsal shield, 420 (410-430); number of acetabula per plate, 40 (35-45).

Dorsal lengths of palp segments: P-I, 35 (32-37); P-II, 139 (134-144); P-III, 62; P-IV, 115 (112-117); P-V, 53 (50-55).

Dorsal lengths of leg segments: I-L-1, 64 (62-65); I-L-2, 78 (74-82); I-L-3, 86 (84-87) ; I-L-4, 115 (112-117); I-L-5, 158 (154-161); I-L-6, 182 (179-184). II-L-1, 74; II-L-2, 85 (82-87); II-L-3, 90 (87-92); II-L-4, 135 (134-136); II-L-5, 177 (174-179); II-L-6, 195 (191-198). III-L-1, 78 (77-79); III-L-2, 86 (82-89); III-L-3, 91 (89-92); III-L-4, 155 (154-156); III-L-5, 219 (216-221); III-L-6, 130 (126-134). IV-L-1, 156; IV-L-2, 116 (114-117); IV-L-3, 88 (84-92); IV-L-4, ---; IV-L-5, 187 (186-188); IV-L-6, 183 (181-184).

Arrangement of swimming hairs: I-L-4, 0; I-L-5, 0. II-L-4, 2; II-L-5, 6. III-L-4, 0; III-L-5, 9. IV-L-4, 2; IV-L-5, 9.

FEMALE: Dorsum (Fig. 2b): Membranous; strongly arched; bearing one pair of small dorsalia; with dorso- and lateroglandularia borne on small, paired, weakly sclerotized plates in integument.

Venter (Fig. 2a): Integument membranous. Coxae I separated in posterior half by strip of integument of width slightly less than that of a coxa I. Coxa I bearing three or four heavy setae at anterior end. Suture between coxa I and coxa II distinct except posteromedially. Coxa II with two or three heavy setae and one fine seta in anterolateral half. Coxoglandularium I situated in narrow strip of integument separating coxa II and coxa III. Coxa III bearing two fine setae in anterolateral half. Suture between coxa III and coxa IV obliterated medially. Coxa IV broadly convex laterally; with three fine setae posteromedial to and one fine seta anteromedial to insertion of leg IV, one fine seta medially. Gonopore borne in integument, with distinct pregenital and postgenital sclerites; flanked by three colinear setae on either side. Pregenital sclerite borne in strip of integument between coxae III and IV of width about two and one half times that of pregenital sclerite. Each acetabular plate borne in integument; extending laterally from near edge 
of gonopore to point posterior to insertion of leg IV; bearing 39-75 acetabula and 2-4 fine setae. Coxoglandularium II, excretory pore and all ventroglandularia borne in integument.

Measurements: Length of coxa I, 293 (280-315); length of coxae III + IV, 410 (392-440); width of coxae I + II, 130 (119-136); width of coxa IV, 285 (258-315); width of acetabular plate, 306 (280-347); length of acetabular plate, 101 (87-124); length of gonopore, 245 (211-267); width of pregenital sclerite, 110 (97-124); width of postgenital sclerite, 76 (67-87); length of chelicera, 320 (300-325); length of dorsalium, 82 (76-89); width of dorsalium, 43 (40-47); number of acetabula per plate, $58(39-75)$.

Dorsal lengths of palp segments: P-I, 37 (35-42); P-II, 138 (129-151); P-III, 69 (62-74); P-IV, 141 (131-154); P-V, 57 (55-62).

Dorsal lengths of leg segments: I-L-1, 82 (77-99); I-L-2, 92 (87-104); I-L-3, 102 (92-114); I-L-4, 150 (134-164) ; I-L-5, 182 (176-198) ; I-L-6, 190 (184-211). II-L-1, 86 (76-102); II-L-2, 103 (97-112); II-L-3, 116 (112-124); II-L-4, 177 (171-193); II-L-5, 217 (211-236); II-L-6, 217 (206-228). III-L-1, 92 (87-99); III-L-2, 110 (99-119); III-L-3, 113 (97-126); III-L-4, 189 (181-203); III-L-5, 241 (231-260); III-L-6, 221 (211-233). IV-L-1, 125 (114-144); IV-L-2, 131 (124-141); IV-L-3, 139 (134-149); IV-L-4, 229 (221-253); IV-L-5, 253 (243-278); IV-L-6, $230(223-238)$.

Arrangements of swimming hairs: I-L-4, 1 or 2 ; I-L-5, 3 to 5. II-L-4, 3 or 4; II-L-5, 8. III-L-4, 4; III-L-5, 9 or 10. IV-L-4, 5; IV-L-5, 9 or 10.

TYPES: Holotype: Male, taken in a small pool near the mouth of the small creek flowing into northwest side of Echo Lake, Baysville, Muskoka District, Ontario $\left(45^{\circ} 11^{\prime} \mathrm{N}, 79^{\circ} 4^{\prime} \mathrm{W}\right) ; 21$ July 1971.

Paratypes: Two males, same data as holotype; 22 females, same locality as holotype; 20-25 July 1971. Holotype deposited in the Department of Entomology and Invertebrate Zoology, Royal Ontario Museum; paratypes in the Royal Ontario Museum, the Canadian National Collection and the Chicago Natural History Museum.

HABITAT: Small pools (maximum width 10 feet, maximum depth 3 feet) with slow current near the mouth of a small, cool creek flowing through mixed forest. Substrate is of fine silt with sparse rooted aquatic vegetation. Most specimens were taken under overhanging banks among roots.

REMARKS: On the basis of the morphology of the female, this species is allocated to a species group with $N$. californica, $N$. pioniformis and $N$. crassa that is characterized by the absence of sclerotized shields in the membranous integument of both dorsum and venter, and by small size. All known males of this species group have the dorsal and ventral shields continuous anteriorly between the eyes. The characters previously used to distinguish species in this group are highly and continuously variable in the N. muskoka population. Separation of these species is greatly hampered by 
lack of knowledge of interspecific variability. For example, Cook (1960), in separating $N$. californica from $N$. crassa on the basis of Viets (1936, fig. 335 ), used the number of heavy setae at the anterior end of coxa I, acetabular number and the shape of the acetabular plates. Not only is the N. muskoka population polymorphic for each of these characters, but the figure of $N$. crassa given by Viets (1936) does not agree with the figure given for this species in the original description by Koenike (1908, fig. 1) in these characters. Until more complete descriptions based on several specimens of each sex are available for all known species of Nautarachna, detailed remarks on their affinities are not possible.

I have collected males and females of $N$. muskoka from silty substrate of a small, cool, slowly flowing creek in Ontario (east side of Highway 11, 3 miles south of Trout Creek, Nipissing District; 14 May 1972, 1 June 1972; ROM). I have taken two females and one male of a species of the muskoka group in Nevada (Cabin Creek near Hinkey Summit, Paradise Valley, Humboldt Co.; 31 May 1968; ROM). These specimens possess very short, wide acetabular plates bearing approximately 20 acetabula per side in the male and 35 acetabula per side in the female. In other characters, these individuals are similar to specimens of $N$. muskoka. They may belong to $N$. californica but this cannot be decided until more western material is available.

\section{Provisional Key to Females of the muskoka Group}

1. Acetabular plates as long as wide (Cook, 1960, fig. 10).

Acetabular plates much wider than long (Fig. 2a)

N. pioniformis Cook

2. Medial edges of acetabular plates extending anteriorly beside gonopore over half its length (Koenike, 1908, fig. 1; Viets, 1936, fig. 335).

N. crassa (Koenike)

Medial edges of acetabular plates extending anteriorly beside gonopore not more than one-third of its length (Fig. 2a)

3. Coxae not marginally augmented by sclerotization of adjacent integument; coxa IV acutely angled posteriorly (Cook, 1960, fig. 1).

N. californica Cook

Coxae marginally augmented by sclerotization of adjacent integument; coxa IV relatively rounded posteriorly (Fig. 2a) .......... muskoka n. sp.

\section{Nautarachna queticoensis $\mathbf{n}$. sp.}

MALE: Dorsum (Fig. 3b): Dorsal shield bearing all pairs of dorsoglandularia and second pair of lateroglandularia; separated from ventral shield anteriorly between eyes by narrow strip of membranous integument.

Venter (Fig. 3a): Coxa I bearing two to four heavy setae at anterior end. Coxa II with two heavy setae and one fine seta in anterolateral half. Coxa IV bearing two or three fine setae posterior to, rarely one fine seta postero- 
medial to and one or two fine setae anteromedial to insertion of leg IV. Gonopore flanked anteriorly by a group of four or five small setae on each side. Each acetabular plate with 58-83 acetabula.

Measurements: Length of coxa I, 350 (344-360); length of coxae, 622 (611-649); width of coxae I + II, 172 (159-184); width of coxa IV, 356 (344-372); width of acetabular plate, 387 (363-410); length of acetabular plate, 111 (92-124); length of gonopore, 64 (60-67); length of chelicera, 396 (382-420); length of dorsal shield, 880 (831-926); width of dorsal shield, 724 (649-783); number of acetabula per plate, 72 (58-83).

Dorsal lengths of palp segments: P-I, 55 (50-57); P-II, 184 (169-188); P-III, 83 (74-92); P-IV, 166 (159-179); P-V, 47.

Dorsal lengths of leg segments: I-L-1, 118 (99-129); I-L-2, 129 (117144); I-L-3, 120 (117-124); I-L-4, 183 (179-186); I-L-5, 248 (246250); I-L-6, 230 (226-241). II-L-1, 119 (112-126); II-L-2, 132 (129136); II-L-3, 129 (124-136); II-L-4, 214 (211-218); II-L-5, 281 (270288 ); II-L-6, 258 (250-265). III-L-1, 123 (119-129); III-L-2, 136 (131149); III-L-3, 130 (124-136); III-L-4, 239 (233-248); III-L-5, 311 (305322 ); III-L-6, 161 (159-174). IV-L-1, 217 (198-228); IV-L-2, 177 (169186); IV-L-3, 131 (124-136); IV-L-4, 235 (226-241); IV-L-5, 306 (303$310)$; IV-L-6, 299 (283-308).

Arrangement of swimming hairs: I-L-4, 1; I-L-5, 2. II-L-4, 1; II-L-5, 3 to 5. III-L-4, 1; III-L-5, 6. IV-L-4, 2; IV-L-5, 3 or 4.

FEMALE: Dorsum (Fig. 4b): Slightly flattened dorsoventrally; nearly covered by dorsal shield bearing all four pairs dorsoglandularia, and second pair lateroglandularia; surrounded by strip of membranous integument bearing other three pairs lateroglandularia.

Venter (Fig. 4a): Most structures incorporated into ventral shield. Posterior half of coxa I fused with ventral shield, suture obliterated medially, weak posteromedially. Coxa I bearing three or four heavy setae at anterior end. Suture between coxa I and coxa II distinct. Coxa II with one heavy seta and three fine setae in anterolateral half; fused with anterior edge of coxa III, including coxoglandularium I. Coxae III fused medially with ventral shield, sutures distinct, separated by distance less than width of gonopore. Coxa III bearing three fine setae in anterolateral half. Suture between coxa III and coxa IV distinct. Coxa IV weakly convex laterally; edges fused with ventral shield, sutures distinct; with two fine setae posterior to and one fine seta anteromedial to edge of insertion of leg IV, two fine setae medially. Gonopore embedded in ventral shield; flanked by two or three setae on either side. Each acetabular plate embedded in ventral shield; extending laterally from near midventral line posterior to gonopore to point beyond level of insertion of leg IV; flanked medially by an arc of three small setae; bearing 85-110 acetabula. Coxoglandularium II and ventroglandularia I and II embedded in ventral shield, ventroglandularia I borne on small, conical projections ventromedial to eyes. Excretory pore and ventroglandularia III, IV and $\mathrm{v}$ situated in membranous integument posterior and lateral to ventral shield. 
Measurements: Length of coxa I, 391 (367-409); length of coxae, 660 (635-669); width of coxae I + II, 225 (208-248); width of coxa IV, 347 (334-360); width of acetabular plate, 485 (461-516); length of acetabular plate, 230 (208-260); length of gonopore, 271 (253-285); length of chelicera, 419 (401-430); length of dorsal shield, 1117 (1041-1184); width of dorsal shield, 919 (869-965); number of acetabula per plate, 97 (87110).

Dorsal lengths of palp segments: P-I, 57 (52-65); P-II, 190 (179-203); P-III, 92 (82-102); P-IV, 194 (188-211); P-V, 65 (62-69).

Dorsal lengths of leg segments: I-L-1, 110 (99-119); I-L-2, 131 (124144); I-L-3, 136 (129-149); I-L-4, 204 (193-211); I-L-5, 262 (248273); I-L-6, 253 (243-263). II-L-1, 118 (112-128); II-L-2, 146 (141159); II-L-3, 147 (141-156); II-L-4, 238 (223-248); II-L-5, 297 (278308); II-L-6, 286 (268-303). III-L-1, 124 (112-129); III-L-2, 152 (146161 ) ; III-L-3, 149 (144-161) ; III-L-4, 260 (248-270); III-L-5, 344 (337$360)$; III-L-6, 303 (290-320). IV-L-1, 196 (188-201); IV-L-2, 183 (176201 ) ; IV-L-3, 189 (176-201) ; IV-L-4, 346 (332-357) ; IV-L-5, 378 (365389); IV-L-6, 333 (315-350).

Arrangement of swimming hairs: I-L-4, 1; I-L-5, 2. II-L-4, 1; II-L-5, 2 to 4. III-L-4, 1 ; III-L-5, 5 or 6 . IV-L-4, 2; IV-L-5, 3 or 4.

TYPES: Holotype: Male taken in a small stream on a hillside on the south side of Highway 11, 5.1 miles west of the entrance to Dawson Trail Campground, Quetico Provincial Park, Rainy River District, Ontario ( $48^{\circ} 40^{\prime} \mathbf{N}$, $\left.91^{\circ} 7^{\prime} \mathrm{W}\right) ; 10$ June 1971.

Paratypes: 11 males, 20 females, same data as holotype. Holotype deposited in the Department of Entomology and Invertebrate Zoology, Royal Ontario Museum; paratypes in the Royal Ontario Museum, the Canadian National Collection and the Chicago Natural History Museum.

HABITAT: Small stream (maximum width 2 feet, maximum depth 6 inches) flowing down a hillside through mixed forest. Substrate varies from fine silt and rocks in pools to vegetation covered rocks in riffles. Specimens were taken in both situations.

REMARKS:This distinctive species is considerably larger and the female much more heavily sclerotized than those of the muskoka group and seems to represent a new subgeneric species group. The characters of the male clearly show its close affinity with the other species of Nautarachna.

I have also collected specimens of $N$. queticoensis in vegetation on rocks in riffle areas of very small streams in Ontario (on south side of Highway 11, 7.2 miles south of Beardmore, Thunder Bay District; 21 June 1971; ROM; and on east side of Highway 127, 9.7 miles south of junction of Highway 127 and Highway 60; 10 May 1972; ROM) and in Quebec (on north side of Highway 59, 12.3 miles west of Arntfield; 25 May 1972; RoM). Two female specimens of Nautarachna (ROM), taken in British Columbia (pool in a small stream crossing the Trans-Canada Highway 19.9 miles north of Golden; 25 July 1969), possess very long acetabular plates bearing 

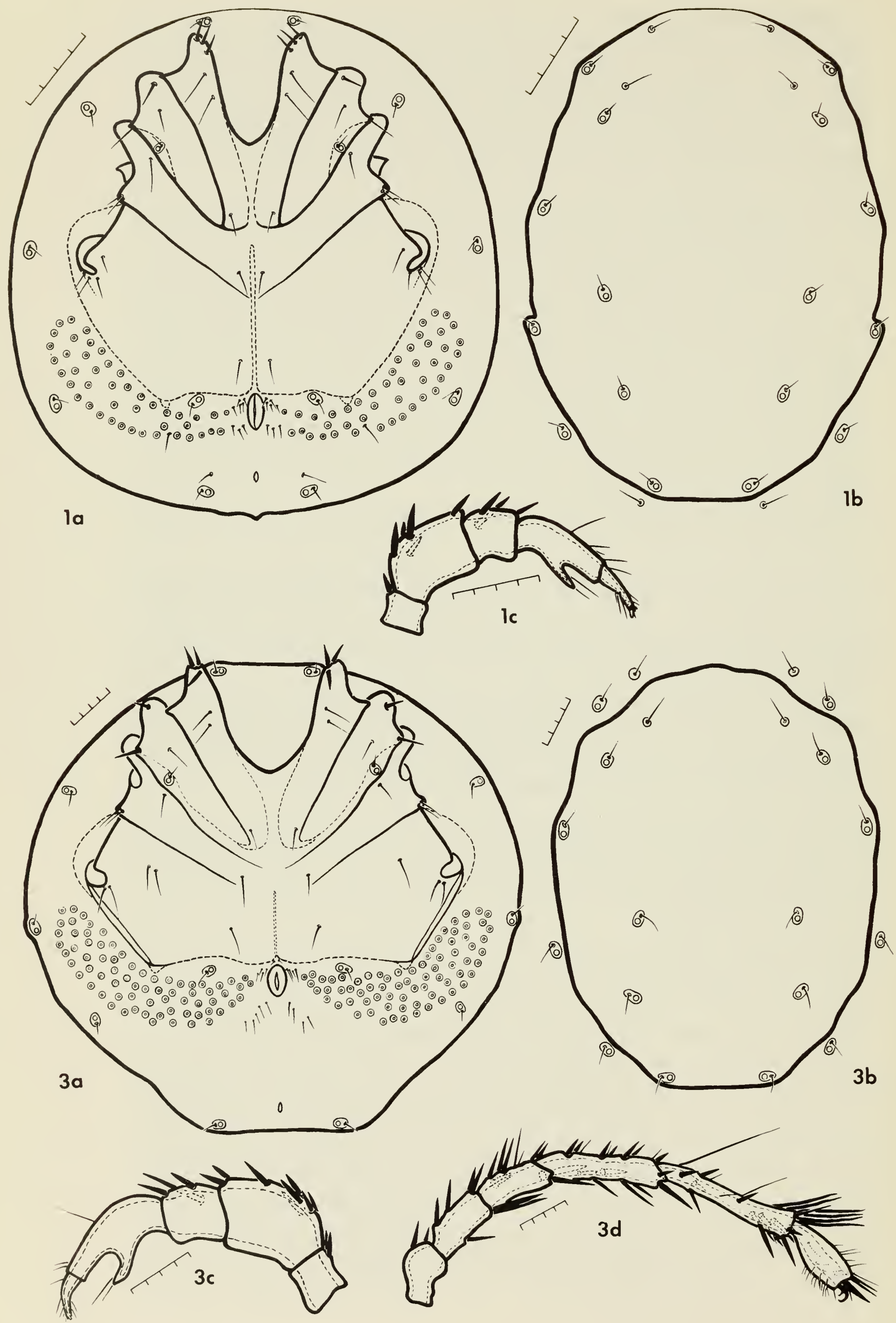


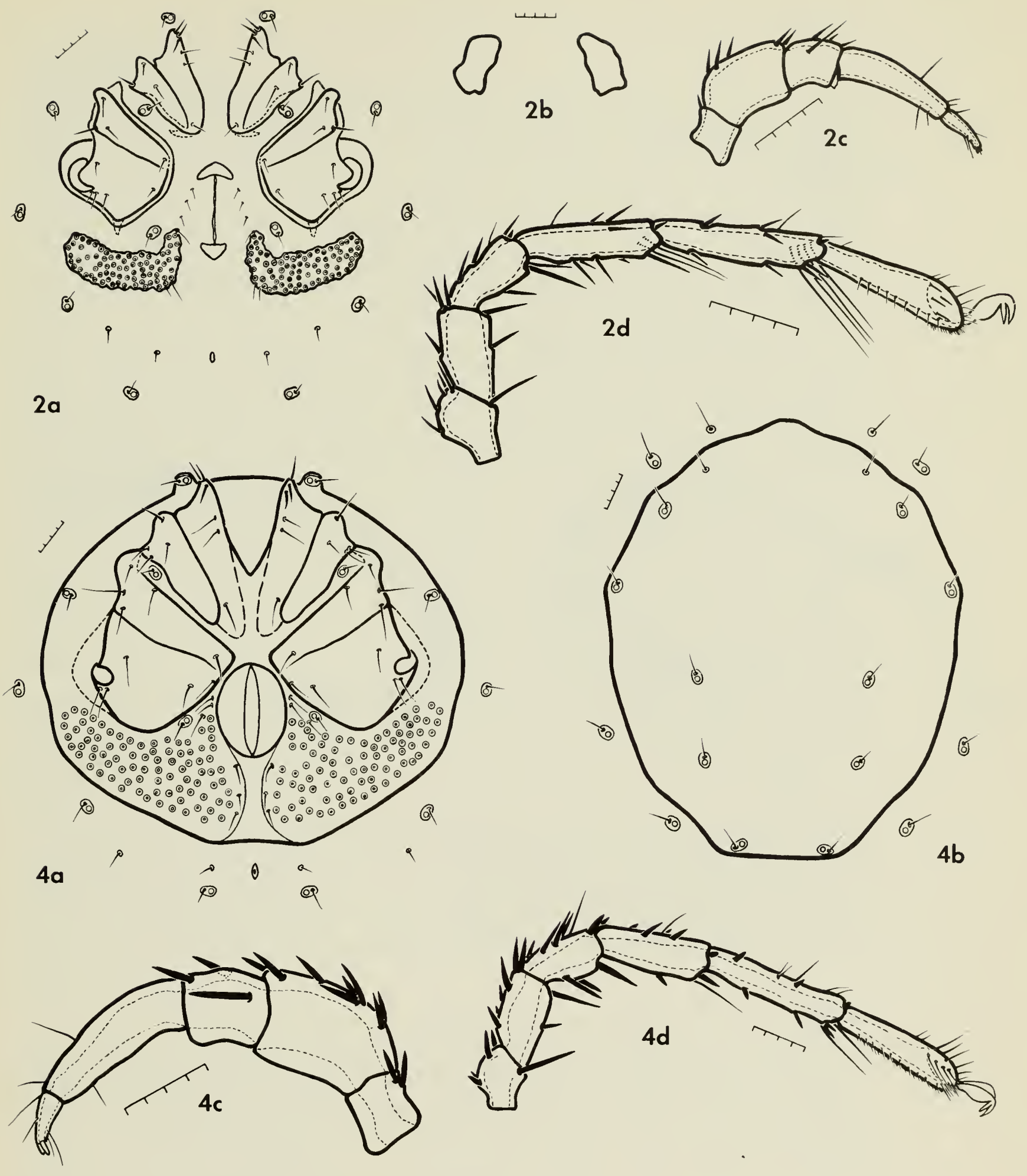

Figs. 1-4 Nautarachna n. spp. (1 scale div. $=25 \mu)$.

1. N. muskoka n. sp. ô: a) ventral view; b) dorsal sclerites; c) palp, lateral view.

2. N. muskoka n. sp. + : a) ventral view; b) dorsalia; c) palp, lateral view; d) $\operatorname{leg} \mathrm{I}$.

3. N. queticoensis n. sp. $\delta$ : a) ventral view; b) dorsal sclerites; c) palp, lateral view; d) leg III.

4. N. queticoensis n. sp. 9 : a) ventral view; b) dorsal sclerites; c) palp, lateral view; d) leg $\mathbf{I}$. 


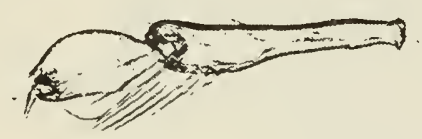

$5 a$

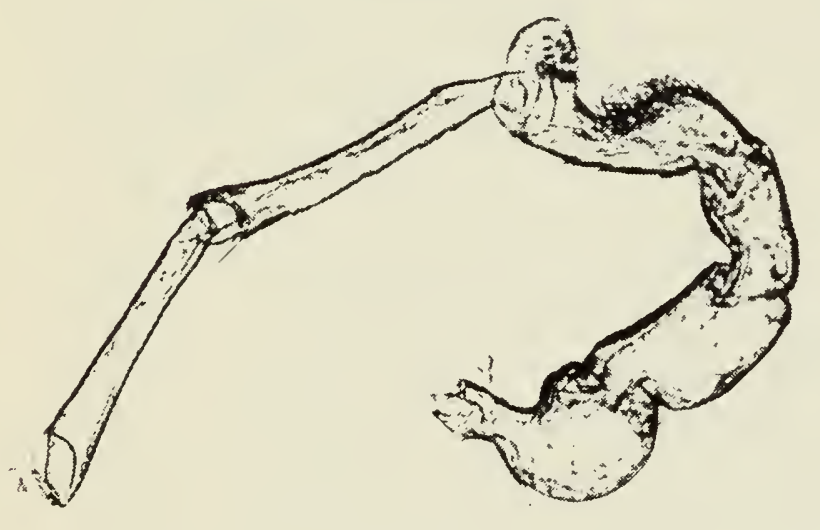

$5 c$

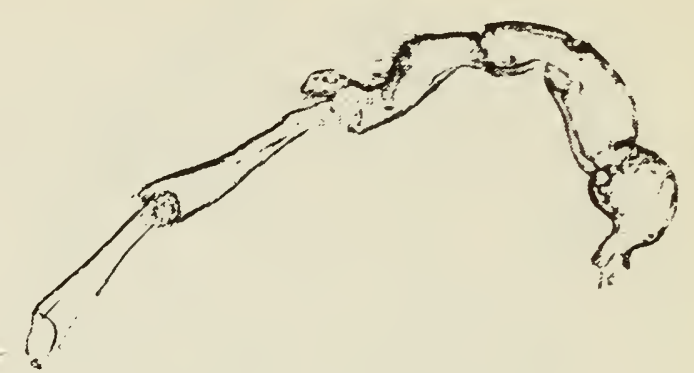

$5 b$

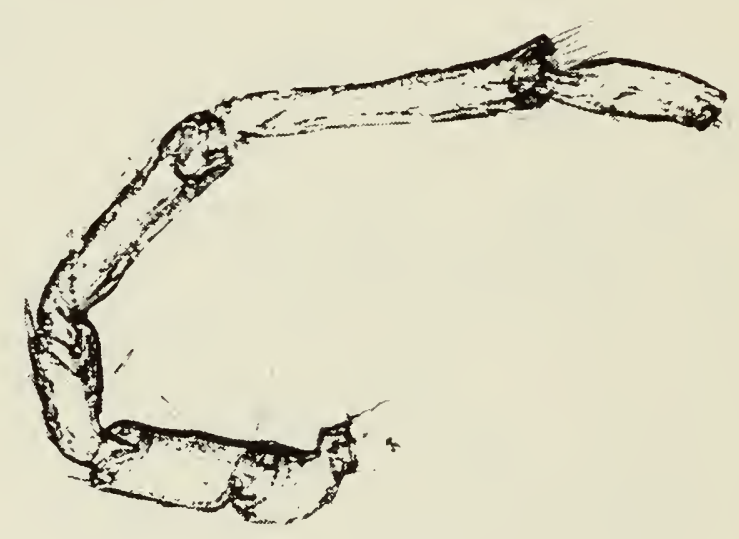

$5 d$

Fig. 5 Nautarachna n. spp. (Scale: $4.8 \mathrm{~mm} .=50 \mu$ ).

a. N. muskoka n. sp. ô III-L-5, 6

b. N. muskoka n. sp. ô Leg IV

c. N. queticoensis n. sp. $\hat{o}$ Leg IV

d. N. queticoensis n. sp. ô Leg III

about 150 acetabula each and certainly belong to this species group. Otherwise, they are similar to $N$. queticoensis. A decision on the systematic status of this population should await the collection of more individuals of both sexes. 


\section{Discussion}

The type of sexual dimorphism exhibited in III-L- 6 and IV-L- 4 by species of Nautarachna indicates their close relationship with species of the genus Piona. Since the modifications of these segments exhibited by males of Nautarachna species are characteristic for the Pioninae, the genus Nautarachna should be placed in this subfamily. Although the genera Nautarachna and Piona have many morphological characters in common, it seems that, on the basis of available material, the genus Nautarachna should be retained for those species of the Pioninae possessing the following characteristics: males with extensive, sclerotized, dorsal and ventral shields; one large, ventromedial, distally-directed, setiferous tubercle on P-Iv; 2-4 heavy setae at anterior end of coxa I; number of swimming hairs relatively few. Females with broadly convex posteromedial edge of coxa IV; no setiferous tubercle on P-IV; three or four heavy setae at anterior end of coxa I; number of swimming hairs relatively few.

The species of Nautarachna appear to form two groups based on the degree of integumentary sclerotization and size. The muskoka group, characterized by anterior connection of dorsal and ventral shields in the male, absence of large dorsal and ventral shields in the female and relatively small size, includes $N$. muskoka, $N$. californica, $N$. pioniformis and $N$. crassa. The queticoensis group, characterized by lack of an anterior connection of dorsal and ventral shields in the male, presence of large dorsal and ventral shields in the female and relatively large size, contains only $N$. queticoensis thus far.

Nautarachna species are local in distribution. This fact, coupled with considerable intraspecific variation, may result in persistent difficulties in establishing species diagnoses based on a few characters. (See remarks under $N$. muskoka.) It would seem advisable to determine the variation that can be expected in a population of Nautarachna before taxonomic decisions are made.

Of the ten described species of Nautarachna, seven have been reported from cool, lotic habitats, one from a freshwater, alpine lake, one from the vicinity of a saline spring and the other from the marine littoral. Walter (1925) and Sokolow (1936) suggested that the occurrence of $N$. asperrima in the ocean was accidental. However, the record from New Brunswick (Habeeb, 1957) may indicate that the relationship of Nautarachna with saline habitats warrants further investigation.

The marked sexual dimorphism in the structure of P-IV in the species of the genus Nautarachna is unusual among water mites and probably contributed to the failure of previous workers to associate the sexes of this genus. The many morphological similarities and the consistent association of these males and females in natural habitats provides undoubted evidence for their congeneric relationship. Further accumulation of material and revisionary work are required to resolve the remaining species level taxonomic difficulties in this genus. 


\section{Acknowledgments}

I acknowledge with gratitude the assistance and encouragement of Drs. Glenn Wiggins and David Barr of the Department of Entomology and Invertebrate Zoology, Royal Ontario Museum. Dr. John Kethley of the Chicago Museum of Natural History loaned holotypes of $N$. californica and $N$. pioniformis. Thanks are due to Messrs. Tosh Yamamoto and Henry Frania for assistance in the collection of specimens, Mr. Anker Odum for criticism of the line drawings and photographs, and Mrs. Judy Allan for typing the manuscript.

The research resulting in this publication was done under a National Research Council Postgraduate Scholarship. This study was supported by a National Research Council of Canada grant to Dr. G. B. Wiggins (grant A5707). Some collections were made during ROM field trips supported by the National Science Foundation (grant GB4021), the Canadian National Sportsmen's Show and the Fisheries Research Board of Canada. 


\section{Literature Cited}

BADER, C.

1955 Hydracarinen-Diagnosen aus dem Nachlass von Dr. C. Walter.

Verh. Naturf. Ges. Basel, vol. 66, no. 1, pp. 61-84.

COOK, D.

1960 Two new species of Nautarachna from Western North America

(Acarina: Nautarachnidae). Ent. News, vol. 71, no. 9, pp. 227-230.

HABEEB, $\mathrm{H}$.

1955 North American Hydrachnellae. XxxII-XxxIV. Leafl. Acadian Biol., no. 7, pp. 1-4.

1956a Notes on watermites. 1. Leafl. Acadian Biol., no. 11, pp. 1-2.

1956b North American Hydrachnellae. XxxIX-XLI. Leafl. Acadian Biol., no. 12 , pp. $1-4$.

1957 Uber Nautarachna karl-vietsi Habeeb, 1956. Abh. naturw. Ver. Bremen, vol. 35, no. 1, pp. 51-52.

HALBERT, J. N.

1944 List of Irish fresh-water mites (Hydracarina). Proc. Ir. Acad., vol. 50, B, no. 4, pp. 39-104.

KOENIKE, F.

1908 Ein neues Hydrachniden-Genus unde eine unbekannte NeumaniaSpecies. Zool. Anz., vol. 32, no. 23, pp. 704-707.

1910 Ein Acarinen-insbesondere Hydracarinen-System nebst hydracarinologischen Berichtigungen. Abh. naturw. Ver. Bremen, vol. 20, no. 1, pp. 121-164.

MONIEZ, R.

1888 Note sur une Hydrachnide Marine, Nautarachna asperrimum, nov. gen., nov. sp. Revue Biologique du Nord de la France, no. 2, pp. 64-68.

NEWELL, I. M.

1959 Acari. In Edmonson, W. T., ed. Fresh-water biology. 2d ed. New York, Wiley, pp. 1080-1116.

SOKOLOW, I.

1936 Uber die Hydracarinen der Quellen und Quellbache des Leningrader Gebietes. Arch. Hydrobiol., vol. 30, no. 3, pp. 463-496.

VIETS, KARL

1935a Die Wassermilben von Sumatra, Java und Bali nach den Ergebnissen der Deutschen Limnologischen Sunda-Expedition. Part I-II. Arch. Hydrobiol., suppl., vol. 13, pp. 484-738.

1935b Die Wassermilben von Sumatra, Java und Bali nach den Ergebnissen der Deutschen Limnologischen Sunda-Expedition. Part III. Arch. Hydrobiol., suppl., vol. 14, pp. 1-113.

1936 Wassermilben oder Hydracarina (Hydrachnellae und Halacaridae). Tierwelt Dtl., vol. 31-32, pp. 1-574.

1937 Uber einige Wassermilben aus Jugoslawien. Zool. Anz., vol. 120, no. 11-12, pp. 294-301.

1956 Die Milben des Süsswassers und des Meeres. Part 2-3. Jena, Fischer Verlag. 870 p.

WALTER, C.

1925 Marine Hygrobatidae. Revision der Wassermilben-Genera Pontarachna Philippi und Nautarachna Moniez. Int. Revue Ges. Hydrobiol. Hydrogr., vol. 14, no. 1-2, pp. 1-54.

YOUNG, W. C.

1969 Ecological Distribution of Hydracarina in North Central Colorado.

Am. Midl. Nat., vol. 82, no. 2, pp. 367-401. 




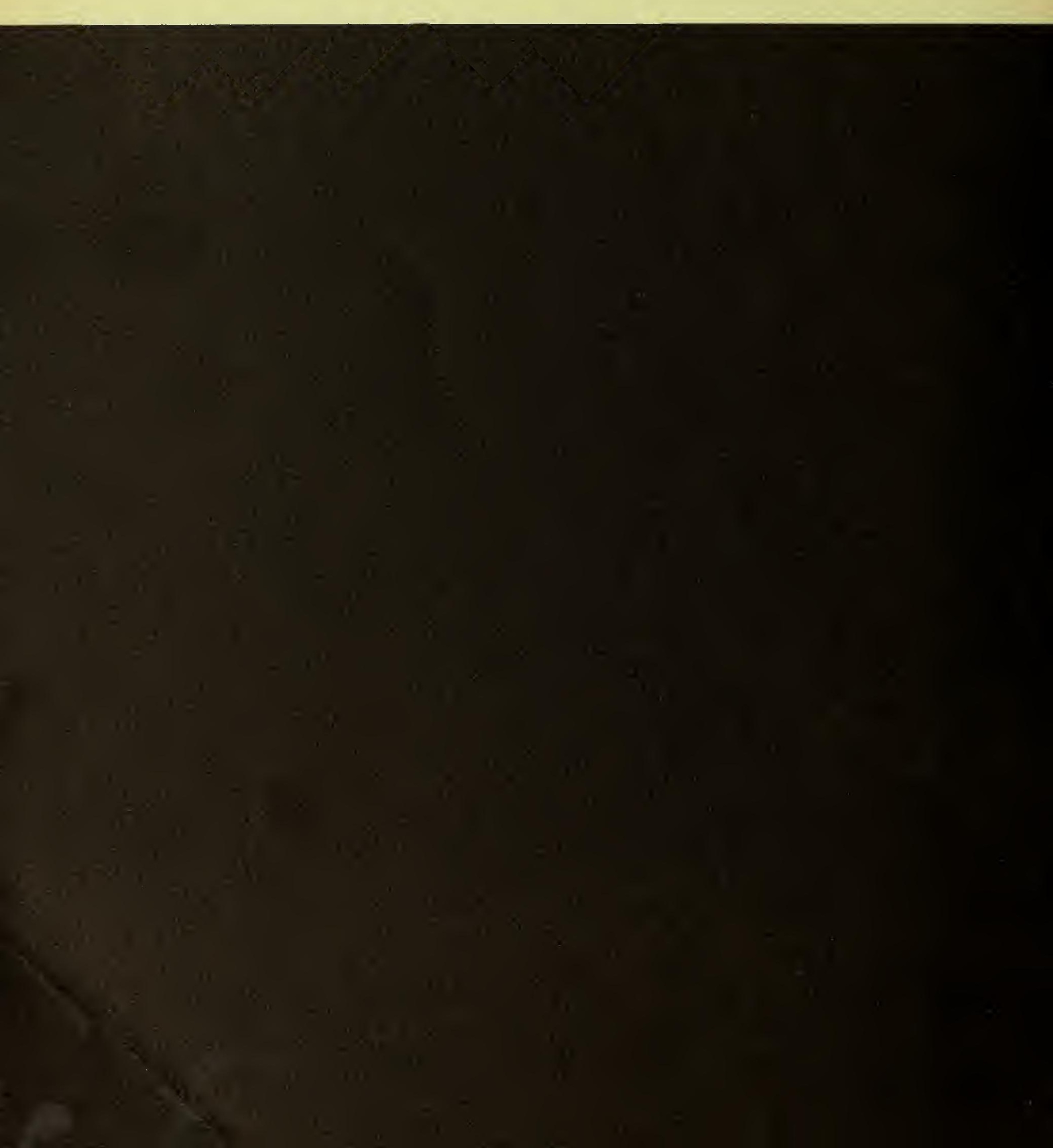

